\title{
Clinical determinants of carotid intima-media thickness in patients with diabetes mellitus type 2
}

\section{Kliniczne determinanty grubości kompleksu intima-media w tętnicach szyjnych u chorych na cukrzyce typu 2}

Wojciech Bartman, Krystyna Pierzchała

Katedra i Klinika Neurologii w Zabrzu, Śląski Uniwersytet Medyczny w Katowicach

Neurologia i Neurochirurgia Polska 2012; 46, 6: 519-528

DOI: 10.5114/ninp.2012.32278

\begin{abstract}
Background and purpose: Early atherosclerotic changes in carotid arteries can be detected using ultrasound examination. The aim of this study was to assess correlations between intima-media thickness (IMT) and gender, age and clinical features of diabetes mellitus (DM).

Material and methods: The study group consisted of 73 patients with type $2 \mathrm{DM}$ (mean age: $63.6 \pm 7.5$ years), and 74 controls without DM (mean age $62.2 \pm 7.5$ years). Analysed clinical features of diabetes included disease duration, anti-diabetic treatment, glycaemic control $\left(\mathrm{HbA}_{1 \mathrm{c}}\right.$ level$)$, presence of metabolic syndrome, and complications of macroand microangiopathy. IMT was measured using ultrasonography in the carotid arteries (common - CCA, bifurcation, internal - ICA) bilaterally.

Results: Mean and maximum IMT in the CCA was greater in diabetic patients than in controls. Age and male sex, but not vascular risk factors, were independent predictors of increased IMT in all segments. Macroangiopathy correlated with IMT within both CCA in univariate analysis. After adjusting for age and gender, this relationship remained significant in the right CCA in middle-aged patients (59-67 years; $p=0.01$ for mean IMT, $p=0.02$ for maximum IMT). In patients without metabolic syndrome, IMT in the right CCA bifurcation correlated with $\mathrm{HbA}_{1 \mathrm{c}}$ level $(p=0.05)$. Patients treated simultaneously with insulin and oral antidiabetic drugs had smaller
\end{abstract}

\section{Streszczenie}

Wstęp i cel pracy: Ultrasonografia tętnic szyjnych umożliwia wykrycie wczesnych zmian miażdżycowych towarzyszących powikłaniom cukrzycy. Celem pracy było określenie zależności grubości kompleksu intima-media (KIM) od płci, wieku oraz cech klinicznych cukrzycy.

Materiał i metody: Zbadano 73 chorych na cukrzycę typu 2 (średnia wieku 63,6 \pm 7,5 roku) oraz 74 osoby bez cukrzycy (średnia wieku: 62,2 $\pm 7,5$ roku). Do cech klinicznych cukrzycy zaliczono: czas trwania choroby, leczenie przeciwcukrzycowe, kontrolę glikemii (stężenie $\mathrm{HbA}_{1 \mathrm{c}}$ ), obecność zespołu metabolicznego oraz powikłań makro- i mikroangiopatycznych. Grubość KIM oceniono ultrasonograficznie obustronnie w trzech segmentach ściany dalszej tętnic szyjnych [wspólnej (CCA), bifurkacji oraz wewnętrznej (ICA)]. Wyniki: U chorych na cukrzycę średnia i maksymalna grubość KIM w CCA była większa niż w grupie kontrolnej. Wiek i płeć męska stanowiły niezależne czynniki rokownicze pogrubienia KIM przy jednoczesnym braku wpływu naczyniowych czynników ryzyka. W analizie jednoczynnikowej wykazano korelację powikłań makroangiopatii z grubością KIM w ob rębie obu CCA. Po uwzględnieniu wieku i płci zależność ta pozostała istotna w prawej CCA u chorych w wieku 59-67 lat ( $p=0,01$ dla średniej grubości KIM i $p=0,02$ dla maksymalnej grubości KIM). U chorych nieobciążonych zespołem metabolicznym stwierdzono korelację grubości KIM w ob -

Correspondence address: dr Wojciech Bartman, Klinika Neurologii Śląskiego Uniwersytetu Medycznego w Katowicach, 3 Maja 13-15, 41-800 Zabrze, Polska, phone: +48 3228528 61, fax: +48603052 530, e-mail: wojbartman@poczta.onet.pl

Received: 28.12.2011; accepted: 30.04.2012 
IMT in the right ICA than those treated with insulin only $(0.471 \pm 0.105$ vs. $0.678 \pm 0.209 \mathrm{~mm} ; p=0.04)$.

Conclusions: In diabetic patients, ultrasound IMT measurement can be used to assess the cardiovascular risk and to determine indications for intensified anti-diabetic treatment. IMT is a sensitive marker of early carotid atherosclerosis, particularly on the right side.

Key words: intima-media thickness, ultrasonography, diabetes mellitus, microangiopathy, macroangiopathy, $\mathrm{HbA}_{1 \mathrm{c}}$.

\section{Introduction}

Atherosclerosis develops progressively in several stages and depends on exogenous and endogenous factors. The contribution of genetic abnormalities is unequivocal and includes mutations leading to the polymorphisms of genes involved in the basic atherothrombotic processes $[1,2]$. Among numerous exogenous factors, the influence of pathological glycation products and the oxidative stress induced by the chronic hyperglycaemia, insulin resistance and hyperinsulinaemia is highlighted [3-5]. Decreased production of nitric oxide (NO), as well as increased concentrations of adhesive molecules and free radicals, increases the endothelial damage, while the insulin resistance antagonizes the positive effects of insulin and accelerates progression of atheromatous lesions $[6,7]$. Increased intima-media thickness (IMT), as visualized with ultrasonography, has important prognostic value for the development of cardiovascular diseases and the development of atherosclerotic lesions in carotid and peripheral arteries [8-15].

A strong correlation was found between IMT thickness and the following variables: age, male sex, arterial hypertension, hyperlipidaemia, smoking, obesity, leukocytosis, concentrations of C-reactive protein, fibrinogen and homocysteine, Chlamydia pneumoniae infection, diabetes mellitus (DM) and insulin resistance [16].

Diabetes mellitus plays a crucial role as an independent risk factor for stroke in $37-42 \%$ of cases, especially among patients younger than 65 [17]. Microangiopathic complications, even in their preclinical stage (microalbuminuria due to nephropathy), are associated with acceleration of the atherosclerotic process and with an increased risk of cardiovascular disorders $[18,19]$. rębie bifurkacji prawej CCA ze stężeniem $\operatorname{HbA}_{1 \mathrm{c}}(\phi=0,05)$. U chorych leczonych jednocześnie insuliną i lekami doustnymi stwierdzono mniejszą średnią grubość KIM w prawej ICA w porównaniu z osobami przyjmującymi wyłącznie insulinę $(0,471 \pm 0,105$ vs 0,678 $\pm 0,209 \mathrm{~mm} ; p=0,04)$.

Wnioski: Grubość KIM u chorych na cukrzycę może służyć do oceny ryzyka chorób układu krążenia oraz ustalenia wskazań do intensyfikacji leczenia przeciwcukrzycowego. Jest czułym wskaźnikiem wczesnych zmian miażdżycowych, a większą wartość kliniczną mają pomiary przeprowadzane w obszarze bifurkacji i tętnicy szyjnej wewnętrznej po stronie prawej.

Słowa kluczowe: kompleks intima-media, ultrasonografia, cukrzyca, makroangiopatia, mikroangiopatia, $\mathrm{HbA}_{1 \mathrm{c}}$.

Atherosclerotic lesions, when assessed ultrasonographically, show faster increase of their area and volume than the more gradual and slow increase of IMT [20], but the high incidence of complications as well as important contribution of vascular and metabolic factors suggest the need for assessment of early lesions of vessel walls in patients with type $2 \mathrm{DM}$ and for the determination of their clinical significance.

The aim of this study was to determine the relationship between IMT thickness assessed in duplex ultrasound examinations and sex, age, or predefined clinical features of DM.

\section{Material and methods}

The study included patients diagnosed with type 2 DM, aged between 50 and 70, who had no more than three risk factors for cardiovascular disorders that have a major impact on IMT in carotid arteries. Those risk factors included arterial hypertension, smoking and dyslipidaemia. The study group involved 73 patients with type 2 DM (mean age: 63.6 years; standard deviation [SD]: 7.5). The control group consisted of 74 subjects without DM (mean age: 62.2 years; SD: 7.5 ).

The protocol of the study was approved by the Bioethical Committee at the Silesian Medical University of Katowice. Each subject provided informed consent to participate in this study.

According to the history and medical records, the following clinical features of DM were defined: (1) disease duration (measured in years since the diagnosis was made); (2) method of anti-diabetic treatment (insulin, oral hypoglycaemics, or combination of insulin and oral medications); (3) control of glycaemia $\left(\mathrm{HbA}_{1 \mathrm{c}}\right.$ level [\%]); 
(4) prevalence of metabolic syndrome, diagnosed according to the International Diabetes Federation criteria; (5) prevalence of macroangiopathic complications (ischaemic heart disease, including myocardial infarction, peripheral artery disease, stroke or transient ischaemic attack [TIA]), analysed further in total; (6) prevalence of microangiopathic complications (retinopathy, nephropathy, neuropathy, diabetic foot), analysed further in total.

The prevalence of arterial hypertension, smoking, obesity, and dyslipidaemia was also noted.

Clinical examination involved the frequency and re gularity of the heart rhythm, measurement of the systolic and diastolic blood pressure, body weight, and body mass index (BMI), as well as the signs of damage to the central and/or peripheral nervous system, including features of diabetic neuropathy.

Intima-media thickness was measured using high resolution duplex sonography (Esaote MyLab60 apparatus). Measurements were performed in patients lying down and with the head turned opposite to the side of the examined artery. A linear ultrasound probe emitting ultrasound with the frequency changing between 5.6 and 8.0 $\mathrm{MHz}$ was used and the lateral approach was utilized. IMT was measured manually in 2D images and B-mode presentation according to the Mannheim Intima-Media Thickness Consensus [9] within the three segments of the far wall of the carotid without atherosclerotic lesions (Fig. 1): (1) at the level of the common carotid artery (CCA), within a $10-\mathrm{mm}$ distance (or $20 \mathrm{~mm}$ if an atherosclerotic lesion was present) from the bifurcation, at five points separated from each other by $2-4 \mathrm{~mm}$; (2) at the level of the bifurcation, at three points chosen in regard of the length of the bifurcation segment and the presence of atherosclerotic lesions; (3) at the level of the internal carotid artery (ICA), at three points within a $10-\mathrm{mm}$ distance from the bifurcation carina, or beyond that distance, if the atherosclerotic lesions were found in that location. The differentiation between thickened intima-media complex and atherosclerotic plaque was made using the definition provided by the Mannheim Carotid Intima-Media Consensus, which describes the latter as a focal structure thicker than $1.5 \mathrm{~mm}$, or a small structure encroaching into the arterial lumen of at least $0.5 \mathrm{~mm}$, or thicker by $>50 \%$ than the surrounding IMT value.

Data from IMT measurements within the CCA bi furcation and the initial ICA segment were provided separately. In each case, maximal and mean values of measurements within the CCA were reported, and the mean values of measurements within the bifurcation and ICA.

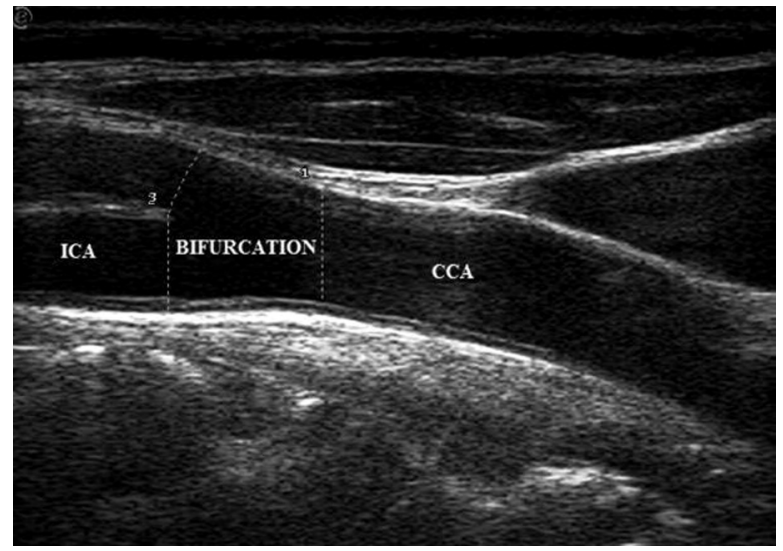

CCA - common carotid artery; ICA - internal carotid artery

Fig. 1. Carotid artery segments according to Mannheim Intima-Media Thickness Consensus

\section{Statistical analysis}

Statistical analysis was performed using the STATISTICA v. 5.5 statistical package as well as Excel 2007. A $p$-value of 0.05 or less was considered statistically significant. Distribution of most quantitative variables deviated significantly from normal (as assessed by ShapiroWilk test); thus, the univariate analyses were performed with non-parametric tests. Comparisons between two groups were made with Mann-Whitney $U$-test, and comparisons among three groups were made with KruskalWallis test. The univariate analysis of dichotomous variables in $2 \times 2$ contingency tables was performed with Fisher exact test, and in the case of $3 \times 2$ contingency tables, a $\chi^{2}$ test with Yates correction was used.

The analysis also included multiple regression. ANCOVA was used to test the effect of independent variables, if they were not presented in an ordinal scale. A logistic regression analysis was used if the dependent variable could be reported as a dichotomous variable. Age and disease duration were considered as the continuous covariables in ANCOVA. Tables include the $p$-value at the moment of removal from the model for the removed variables and the $p$-value for those variables that were left in the model. In the case of independent variables measured on an ordinal scale, a $p$-value is accompanied by a '+' or '-' sign to show the direction of relationship between dependent and independent variables (a ' + ' sign means that an increased value of the independent variable increases the value of the dependent variable and vice versa). A ' $+M$ ' sign was added in cases where male sex had an important effect on the dependent variable. 


\section{Results}

Patients with type 2 DM were similar to controls regarding sex and age. Table 1 provides demographic characteristics, as well as clinical and biochemical features of patients and controls. The distribution of the analysed cardiovascular risk factors among patients with type $2 \mathrm{DM}$ and controls is also provided in Table 1. Obesity, metabolic syndrome, arterial hypertension and cardiovascular risk factors (macroangiopathic complications) were all more prevalent in patients with type 2 DM (Table 1).

Vast atherosclerotic lesions in examined segments of vessels, and, to a minor extent, also pathological obesity, precluded IMT assessment in $6.5 \%$ of patients with type 2 DM (29/444 segments), and in $2.7 \%$ of controls (12/438 segments). The completeness of measurements was highest in CCA (100\% in both groups) and the lowest in ICA (90\% in patients and $96 \%$ in controls).
Mean and maximal IMT was significantly greater in DM patients than in controls (Table 2).

Age and male sex, but not vascular risk factors, were independent predictors of increased IMT in all segments among patients with DM.

Univariate analysis showed a significant correlation between the presence of macroangiopathic complications and the IMT within the left and right CCA. Multiple regression analysis showed a strong effect of (1) age on the IMT in both CCAs and in the right-sided bifurcation, (2) male sex on the IMT in all left-sided segments, and (3) duration of the disease on the IMT within the left ICA. All those factors attenuated the correlation shown in univariate analysis with the exception of patients aged 59-67, in whom the correlation of IMT with the macroangiopathic complications remained significant for the right CCA (Tables 3 and 4). Among patients aged between 59 and 67, a significant influence

Table 1. Age, gender, clinical and biochemical characteristics in diabetic patients and controls

\begin{tabular}{|c|c|c|c|}
\hline & $\begin{array}{l}\text { Patients with diabetes } \\
\qquad(n=73)\end{array}$ & $\begin{array}{l}\text { Controls } \\
(n=74)\end{array}$ & P-value \\
\hline Age $[$ years $]$, mean $\pm \mathrm{SD}$ & $63.6 \pm 7.5$ & $62.2 \pm 7.5$ & 0.30 \\
\hline Women & $37(50.68 \%)$ & $45(60.81 \%)$ & 0.22 \\
\hline Arterial hypertension & $60(82 \%)$ & $49(66 \%)$ & 0.03 \\
\hline Dyslipidaemia & $56(77 \%)$ & $49(65 \%)$ & 0.21 \\
\hline Smoking & $10(14 \%)$ & $13(17 \%)$ & 0.67 \\
\hline \multicolumn{4}{|l|}{ Subjects treated with: } \\
\hline oral hypoglycaemics & $36(49.3 \%)$ & - & - \\
\hline insulin & $24(32.9 \%)$ & - & - \\
\hline insulin and oral hypoglycaemics & $13(17.8 \%)$ & - & - \\
\hline statins & $44(60.3 \%)$ & $28(37.8 \%)$ & 0.01 \\
\hline any hypotensive drug & $52(71.2 \%)$ & $34(43.2 \%)$ & 0.003 \\
\hline Microangiopathy & $32(43.8 \%)$ & - & - \\
\hline Macroangiopathy & $42(57.5 \%)$ & $30(40.54 \%)$ & 0.04 \\
\hline Blood fasting glucose $[\mathrm{mmol} / \mathrm{L}] ;$ mean $\pm \mathrm{SD}$ & $8.05 \pm 2.44$ & $5.64 \pm 1.11$ & $<0.000001$ \\
\hline $\mathrm{HbA}_{1 \mathrm{c}}$ level $[\%]$ & $7.43 \pm 1.29$ & - & - \\
\hline Obesity & $37(51 \%)$ & $17(23 \%)$ & 0.004 \\
\hline Body mass index; mean $\pm \mathrm{SD}$ & $30.29 \pm 4.95$ & $27.22 \pm 3.99$ & 0.08 \\
\hline Metabolic syndrome & $55(75 \%)$ & $29(39.2 \%)$ & 0.00002 \\
\hline Diabetes duration [years]; mean $\pm \mathrm{SD}$ & $11.7 \pm 8.1$ & - & - \\
\hline
\end{tabular}

$S D$ - standard deviation

Data are presented as $n$ (\%), if not otherwise stated. 
Table 2. Mean values of intima-media thickness in diabetic patients and controls

\begin{tabular}{|c|c|c|c|}
\hline & \multicolumn{2}{|c|}{ Intima-media thickness [mm] } & \multirow[t]{2}{*}{$P$-value } \\
\hline & $\begin{array}{c}\text { Diabetic patients } \\
n=73\end{array}$ & $\begin{array}{c}\text { Control group } \\
n=74\end{array}$ & \\
\hline Max. right CCA & $0.852 \pm 0.2$ & $0.763 \pm 0.185$ & 0.004 \\
\hline Mean right CCA & $0.731 \pm 0.167$ & $0.667 \pm 0.155$ & 0.01 \\
\hline Mean right bifurcation & $0.816 \pm 0.263$ & $0.788 \pm 0.227$ & 0.3 \\
\hline Mean right ICA & $0.593 \pm 0.206$ & $0.557 \pm 0.189$ & 0.17 \\
\hline Max. left CCA & $0.916 \pm 0.236$ & $0.786 \pm 0.162$ & 0.0004 \\
\hline Mean left CCA & $0.775 \pm 0.19$ & $0.681 \pm 0.133$ & 0.0009 \\
\hline Mean left bifurcation & $0.866 \pm 0.23$ & $0.8 \pm 0.247$ & 0.09 \\
\hline Mean left ICA & $0.616 \pm 0.218$ & $0.552 \pm 0.167$ & 0.1 \\
\hline
\end{tabular}

$C C A$ - common carotid artery; $I C A$ - internal carotid artery

Table 3. Comparison of age, gender, and intima-media thickness in relation to the macro- and microangiopathic complications in diabetic patients (univariate analysis)

\begin{tabular}{|c|c|c|c|c|c|c|}
\hline & $\begin{array}{c}\text { Patients with } \\
\text { macroangiopathy } \\
(n=43)\end{array}$ & $\begin{array}{l}\text { Patients without } \\
\text { macroangiopathy } \\
(n=30)\end{array}$ & $P$-value & $\begin{array}{c}\text { Patients with } \\
\text { microangiopathy } \\
(n=32)\end{array}$ & $\begin{array}{l}\text { Patients without } \\
\text { microangiopathy } \\
(n=41)\end{array}$ & $P$-value \\
\hline Age [years] ${ }^{*}$ & $66 \pm 6.8$ & $60 \pm 7.5$ & 0.004 & $65 \pm 7.6$ & $62 \pm 7.3$ & 0.12 \\
\hline $\operatorname{Men}[n(\%)]$ & $22(51)$ & $14(47)$ & 0.18 & $12(37.5)$ & $24(58)$ & 0.10 \\
\hline \multicolumn{7}{|c|}{ Intima-media thickness $[\mathrm{mm}]^{*}$} \\
\hline Mean left CCA & $0.807 \pm 0.203$ & $0.724 \pm 0.164$ & 0.03 & $0.806 \pm 0.208$ & $0.751 \pm 0.173$ & 0.20 \\
\hline Max. left CCA & $0.962 \pm 0.249$ & $0.85 \pm 0.2$ & 0.03 & $0.95 \pm 0.24$ & $0.89 \pm 0.23$ & 0.22 \\
\hline $\begin{array}{l}\text { Mean left } \\
\text { bifurcation }\end{array}$ & $0.907 \pm 0.240$ & $0.81 \pm 0.199$ & 0.09 & $0.851 \pm 0.208$ & $0.88 \pm 0.247$ & 0.82 \\
\hline Mean left ICA & $0.625 \pm 0.222$ & $0.6 \pm 0.215$ & 0.52 & $0.653 \pm 0.211$ & $0.59 \pm 0.22$ & 0.18 \\
\hline Mean right CCA & $0.757 \pm 0.138$ & $0.687 \pm 0.197$ & 0.05 & $0.726 \pm 0.153$ & $0.734 \pm 0.18$ & 0.86 \\
\hline Max. right CCA & $0.878 \pm 0.161$ & $0.81 \pm 0.242$ & 0.12 & $0.85 \pm 0.197$ & $0.85 \pm 0.20$ & 0.95 \\
\hline $\begin{array}{l}\text { Mean right } \\
\text { bifurcation }\end{array}$ & $0.865 \pm 0.266$ & $0.815 \pm 0.256$ & 0.34 & $0.845 \pm 0.29$ & $0.847 \pm 0.243$ & 0.57 \\
\hline Mean right ICA & $0.593 \pm 0.213$ & $0.585 \pm 0.2$ & 0.90 & $0.65 \pm 0.24$ & $0.55 \pm 0.17$ & 0.15 \\
\hline
\end{tabular}

*mean \pm standard deviation

$C C A$ - common carotid artery; ICA - internal carotid artery

of macroangiopathic complications was noted for mean IMT in the right CCA $[\mathrm{F}(1,21)=7.51, p=0.01]$ and for maximum IMT in the right CCA $[\mathrm{F}(1,21)=7.01$, $p=0.02]$. Presence of complications was associated with higher values of those measurements. No correlation was found between IMT and the presence of microangiopathic complications among DM patients.

Intima-media thickness did not correlate with $\mathrm{HbA}_{1 \mathrm{c}}$ concentration in the whole study group. When patients with metabolic syndrome were excluded, such a corre- lation was found for the mean IMT within the bifurcation of the right CCA (Spearman rank correlation coefficient, $r=0.61, p=0.05$ ).

A significant association was found between the method of anti-diabetic treatment and the mean and maximal IMT within the right CCA and the mean IMT within the right ICA - the lowest IMT in those segments was noted among patients treated with oral hypoglycaemics when compared to those treated with insulin alone or to the patients treated with both insulin and oral 
Table 4. Intima-media thickness (IMT) in relation to clinical characteristics of diabetes characteristics - multiple regression analysis (p-values are reported; for significant relationships, beta coefficient values with respective standard errors were also provided)

\begin{tabular}{|c|c|c|c|c|c|}
\hline IMT & Age & Gender & Diabetes duration & Macroangiopathy & Microangiopathy \\
\hline Mean left CCA & $\begin{array}{c}0.002(+) \\
\beta=0.34 \pm 0.11\end{array}$ & $\begin{array}{c}0.008(+\mathrm{M}) \\
\beta=0.29 \pm 0.11\end{array}$ & 0.39 & 0.41 & 0.13 \\
\hline Max. left CCA & $\begin{array}{c}0.02(+) \\
\beta=0.26 \pm 0.11\end{array}$ & $\begin{array}{c}0.004(+\mathrm{M}) \\
\beta=0.33 \pm 0.11\end{array}$ & 0.21 & 0.29 & 0.11 \\
\hline Mean left bifurcation & 0.34 & $\begin{array}{c}0.04(+\mathrm{M}) \\
\beta=0.25 \pm 0.12\end{array}$ & 0.47 & 0.26 & 0.86 \\
\hline Mean left ICA & 0.17 & $\begin{array}{c}0.03(+\mathrm{M}) \\
\beta=0.27 \pm 0.12\end{array}$ & 0.72 & 0.71 & 0.23 \\
\hline Mean right CCA & $\begin{array}{c}0.003(+) \\
\beta=0.37 \pm 0.11\end{array}$ & 0.72 & $\begin{array}{c}0.07(+) \\
\beta=0.20 \pm 0.11\end{array}$ & 0.36 & 0.13 \\
\hline Max. right CCA & $\begin{array}{c}0.004(+) \\
\beta=0.35 \pm 0.11\end{array}$ & 0.63 & $\begin{array}{c}0.06(+) \\
\beta=0.22 \pm 0.11\end{array}$ & 0.59 & 0.18 \\
\hline Mean right bifurcation & $\begin{array}{c}0.03(+) \\
\beta=0.27 \pm 0.12\end{array}$ & 0.28 & 0.46 & 0.99 & 0.63 \\
\hline Mean right ICA & 0.08 & 0.60 & $\begin{array}{c}0.005(+) \\
\beta=0.35 \pm 0.12\end{array}$ & 0.57 & 0.33 \\
\hline
\end{tabular}

$C C A-$ common carotid artery; ICA - internal carotid artery

'+' sign means that an increased value of the independent variable increases the value of the dependent variable.

$A$ ' $+M$ ' sign suggests that male sex has an important effect on the dependent variable.

Table 5. Characteristics of diabetic patients treated with insulin alone or taking insulin and oral hypoglycaemics together

\begin{tabular}{|lcc|}
\hline & $\begin{array}{c}\text { Diabetic patients } \\
\text { treated with insulin only } \\
(\mathbf{n}=\mathbf{2 4 )}\end{array}$ & $\begin{array}{c}\text { Diabetic patients treated } \\
\text { both with insulin } \\
\text { and oral hypoglycaemics } \\
\mathbf{( n = 1 3 )}\end{array}$ \\
\hline Maximal daily dose of insulin $[\mathrm{IU}]$ & $53.04 \pm 21.8$ & $49.8 \pm 22.2$ \\
\hline Obesity, $n(\%)$ & $11(45.8 \%)$ & $12(92.3 \%)$ \\
\hline Metabolic syndrome, $n(\%)$ & $20(83.33 \%)$ & $11(84.6 \%)$ \\
\hline Systolic blood pressure $[\mathrm{mm} \mathrm{Hg}]$ & $142.9 \pm 19.67$ & $144.6 \pm 16.13$ \\
\hline Diastolic blood pressure $[\mathrm{mm} \mathrm{Hg}]$ & $80.42 \pm 11.97$ & $78.07 \pm 10.9$ \\
\hline HbA ${ }_{1 \mathrm{c}}[\%]$ & $7.89 \pm 1.1$ & $7.41 \pm 1.38$ \\
\hline LDL $[\mathrm{mmol} / \mathrm{L}]$ & $3.23 \pm 1.2$ & $2.68 \pm 0.8$ \\
\hline HDL $[\mathrm{mmol} / \mathrm{L}]$ & $1.25 \pm 0.29$ & $1.23 \pm 0.23$ \\
\hline Triglycerides $[\mathrm{mmol} / \mathrm{L}]$ & $2.00 \pm 1.07$ & $1.97 \pm 0.52$ \\
\hline Statins, $n(\%)$ & $13(54.2 \%)$ & $8(61.5 \%)$ \\
\hline
\end{tabular}

$S D$ - standard deriation

Data are presented as mean \pm standard deviation, if not otherwise stated.

hypoglycaemics (mean IMT in right CCA $=0.692 \pm$ 0.157 vs. $0.790 \pm 0.164$ vs. $0.727 \pm 0.418 \mathrm{~mm}$, respectively, $p=0.03$; maximum IMT in right $\mathrm{CCA}=0.804$ \pm 0.104 vs. $0.920 \pm 0.210$ vs. $0.862 \pm 0.245 \mathrm{~mm}$, respectively, $p=0.03$; mean $\mathrm{IMT}$ in right $\mathrm{ICA}=0.569$ \pm 0.206 vs. $0.678 \pm 0.209$ vs. $0.471 \pm 0.105 \mathrm{~mm}$, respectively, $p=0.01$ ). Duration of the disease correlated positively with mean and maximal values of IMT in the right CCA, as well as with mean IMT values in the right ICA. It is worth noting that patients receiving oral 
hypoglycaemics had shorter duration of the disease (8.5 \pm 6.4 years) than those treated with insulin alone (14.4 \pm 9.0 years) or patients receiving both insulin and oral hypoglycaemics $(15.6 \pm 7.5$ years, $p=0.002)$. Therefore, a separate analysis was performed among patients treated either with insulin or both with insulin and oral hypoglycaemics, in whom the duration of the disease was similar. Again, in patients receiving combined treatment, lower mean IMT was noted in the right ICA. Patients receiving combined treatment were more often obese, had higher $\mathrm{BMI}$, lower $\mathrm{HbA}_{1 \mathrm{c}}$ concentration and lower LDL cholesterol concentration, and received statins more commonly (Table 5).

\section{Discussion}

Diabetes mellitus is an independent risk factor for atherosclerosis and resulting cardiovascular complications. Patients with impaired glucose tolerance and, to a greater extent, DM patients have increased IMT [21]. Increased IMT in carotid arteries can be noted even in patients diagnosed de novo with DM, which suggests that this abnormality occurs before the clinical manifestation of the disease [22]. Major determinants of increased IMT among diabetic patients include obesity, dyslipidaemia and hyperinsulinaemia, which constitute the cardinal features of insulin resistance syndrome. Thickening of the intima-media complex is especially clear in patients who have experienced macroangiopathic complications [23].

Intima-media thickness within the CCA is greater in diabetic patients than in controls, especially on the left, which results from the anatomical and hemodynamic differences in the biomechanical forces affecting the vessel wall and generated by the blood flow on both sides [24].

Age and male sex were strong determinants of IMT in diabetic patients, similarly to the relationship noted in healthy subjects. No relationship was found between IMT and analysed cardiovascular risk factors (although the $p$-value was close to significant in the case of IMT within the bifurcation of the right CCA), probably be cause of the strong impact of age and due to the greater impact of the metabolic abnormalities typical for DM, as noted also by others $[25,26]$.

We observed an association between IMT and the prevalence of macroangiopathic complications of DM; this association remained significant in patients aged 58-67 when the impact of age and male sex was controlled for.
A strong association between IMT and vascular risk factors, ischaemic heart disease and symptomatic atherosclerosis in other locations, including stroke, has been confirmed in numerous studies [27-29].

Among patients with stroke of atherothrombotic origin, the risk of stroke increases proportionally to the IMT, and greater IMT within the CCA is associated with increased risk of stroke recurrence [30]. Our findings confirm the significance of IMT assessed with ultrasonography as a predictor of cardiovascular disease risk in patients with type $2 \mathrm{DM}$. It is interesting that a correlation was found in some segments of the studied arteries between IMT and glycaemic control as defined by the $\mathrm{HbA}_{1 \mathrm{c}}$ concentration. It was shown in patients with DM who had no metabolic syndrome, and in whom the disturbances related to the disease itself prevail over the effect of cardiovascular risk factors.

Both the ARIC and INVADE studies showed that the $\mathrm{HbA}_{1 \mathrm{c}}$ concentration is an independent factor related to the IMT in patients with DM and with cardiovascular disease risk [31]. No cut-off point for the development of complications was suggested, however. Nevertheless, it was stated that the reduction of $\mathrm{HbA}_{1 \mathrm{c}}$ concentration by $1 \%$ decreases the risk of incident myocardial infarction by $14 \%$ and stroke by $11 \%$. There was no difference, however, in terms of the incidence of cardiovascular complications between those treated aggressively $\left(\mathrm{HbA}_{1 \mathrm{c}} \leq 7.0 \%\right)$ and patients receiving dietary treatment only $\left(\mathrm{HbA}_{1 \mathrm{c}}=7.9 \%\right)$ during the 15 -year follow-up $[32,33]$.

Better glycaemic control translates into the dynamics of the development of early atherosclerotic lesions and into the decreased risk of cardiovascular diseases, as suggested by the meta-analysis of ACCORD, ADVANCE, UKPDS, and VADT studies [34]. Even in patients with good glycaemic control $\left(\mathrm{HbA}_{1 \mathrm{c}}=5.8-6.4 \%\right)$ further improvement in glycaemic control prevents thickening of the intima-media complex in carotid arteries, and ultrasonography is a valuable method enabling monitoring of the progression of those lesions [35]. IMT depends on the duration of the $\mathrm{DM}$, while the increase of $\mathrm{HbA}_{1 \mathrm{c}}$ by $1 \%$ per year of the disease increases the risk of intimamedia thickening by $30 \%$ [36].

The gradual increase of the atherosclerotic lesions in carotid arteries, noted in healthy subjects, patients with newly diagnosed DM and in those with previously diagnosed DM, points to the important effect of disease duration on atherosclerosis development within the carotid arteries and to the presence of the lesions even in a preclinical stage [37]. 
We have analysed the possible impact of anti-diabetic treatment and found significantly smaller IMT in patients receiving oral hypoglycaemics. They had the shortest disease duration, which persuaded us to perform a separate analysis limited to patients treated with insulin only or with insulin plus oral hypoglycaemics who had similar duration of the disease. It showed the advantage of the combined treatment for the IMT in the right ICA. Few studies have been published so far regarding the IMT within the carotids in patients treated with insulin only and in those treated with oral agents; their results are divergent. Large prospective studies conclude that more intense anti-diabetic treatment may result in significantly lower incidence of serious cardiovascular complications [34]. This applies to patients treated with oral hypoglycaemics and to those receiving insulin. The EDIC study, conducted in young (13-40 years) patients without additional cardiovascular risk factors, did not show significant differences in IMT within CCA or ICA between those treated aggressively and in patients treated conventionally. Intensive therapy with insulin reduced the risk of any incident cardiovascular complication by $42 \%$, reduced the risk of myocardial infarction or stroke by $57 \%$ and significantly reduced the risk of microangiopathic complications [38].

Comparison of type $2 \mathrm{DM}$ patients treated with insulin of mixed content (Mix 30) and those receiving insulin injections more often (4 times daily) showed a beneficial effect of more aggressive treatment on the glycaemic control $\left(\mathrm{HbA}_{1 \mathrm{c}}\right.$ concentration) but not for the IMT in carotid arteries [39]. Six-month observation suggested a benefit of intensive polytherapy (three oral medications with divergent mechanisms of action) in terms of the IMT in carotid arteries among patients with newly ( $<1$ year) diagnosed DM $(0.88 \pm 0.26 \mathrm{~mm}$ vs. $0.96 \pm 0.22 \mathrm{~mm}$ ) [40]. New and more persuasive evidence may be provided by the Copenhagen Insulin and Metformin Therapy Trial (CIMT), which began in 2008 and whose final findings are expected in 2014. The primary outcome is the progression of the IMT in carotid arteries in patients with type $2 \mathrm{DM}$ treated simultaneously with insulin and metformin in compari son to those treated with insulin only [41].

In our study, patients receiving aggressive treatment were more frequently treated also with statins with consequent normalization of lipid profile; no association was found between the IMT and the presence of dyslipidaemia. It is worth, however, taking into account the vast and pleiotropic mechanism of action of statins, which is independent of their lipid-lowering effect [42].
Our findings suggest that the intensification of anti-diabetic treatment has a positive impact on the early changes occurring in the ICAs and, indirectly, on the risk of cardiovascular diseases.

It is noteworthy that most of the correlations among IMT and analysed clinical features of DM were related to the specific segments and predominated on the right side. IMT in young subjects does not differ between sides [43], while in the following years it is greater on the left. Among subjects aged over 65 and burdened with cardiovascular diseases this difference diminishes [44], suggesting the domination of the atherosclerotic processes over the biomechanical forces remodelling the vessel walls. It may be supposed that the decreased adaptation of the carotid artery walls to the haemodynamic conditions is responsible for the excessive response and the faster progression of abnormalities on the right side. Greater IMT on the right side was reported in patients with borderline hypertension or with isolated systolic hypertension; IMT of the right CCA is also a predictor of acute coronary events in patients with stable ischaemic heart disease [45]. The diverse distribution of lesions within the walls of carotid arteries has also been reported by others. The results of the CARDIA study suggested that DM, arterial hypertension and smoking had a greater impact on IMT within the bifurcation, while the LDL concentration affected mostly IMT within the ICA [46].

In the CAPS study, vascular risk factors, including diabetes, correlated to a greater extent with the IMT progression in the ICA than in the CCA [47]. This suggests the divergent response of the intima-media complex on each side for the effect of specific haemodynamic, metabolic and biochemical factors, and the divergent predictive value of the measurements performed within the carotid arteries on both sides.

\section{Conclusions}

1. The findings of this study confirm the high utility of ultrasonographic assessment of IMT in patients with type $2 \mathrm{DM}$ as a sensitive marker of early atherosclerotic changes in carotid arteries, showing the greater clinical value of measurements performed within the bifurcation and ICA on the right side.

2. The association between IMT in carotid arteries and the occurrence of macroangiopathic complications and glycaemic control in diabetic patients in a specific age and with vascular risk factors, as well as the association between IMT and the method of anti-diabetic 
treatment, might be used for the assessment of risk of cardiovascular diseases and for the determination of indications for more aggressive treatment in order to achieve optimal metabolic control.

\section{Disclosure}

Authors report no conflict of interest.

\section{References}

1. Juo S.H. Genetics of carotid atherosclerosis. Front Biosci 2009; 14: 4525-4534.

2. Lusis A.J., Mar R., Pajukanta P. Genetics of atherosclerosis. Ann Rev Genomics Hum Genet 2004; 5: 189-218.

3. Pinkney J.H., Stehouwer C.D., Coppack S.W., et al. Endothelial dysfunction: cause of the insulin resistance syndrome. Diabetes 1997; 46 (Suppl 2): 9-13.

4. Georges J.L., Rupprecht H.J., Blankenberg S., et al. Impact of pathogen burden in patients with coronary artery disease in relation to systemic inflammation and variation in genes encoding cytokines. Am J Cardiol 2003; 92: 515-521.

5. Cersosimo E., DeFronzo R.A. Insulin resistance and endothelial dysfunction: the road map to cardiovascular diseases. Diabetes Metab Res Rev 2006; 22: 423-436.

6. Giacco F., Brownlee M. Oxidative stress and diabetic complications. Circ Res 2010; 107: 1058-1070.

7. Potenza M.A., Gagliardi S., Nacci C., et al. Endothelial dysfunction in diabetes: from mechanisms to therapeutic targets. Curr Med Chem 2009; 16: 94-112.

8. Stary H.C., Chandler A.B., Dinsmore R.E., et al. A definition of advanced types of atherosclerotic lesions and a histological classification of atherosclerosis. A report from the Committee on Vascular Lesions of the Council on Arteriosclerosis, American Heart Association. Circulation 1995; 92: 1355-1374.

9. Touboul P.J., Hennerici M.G., Meairs S., et al. Mannheim Carotid Intima-Media Thickness Consensus (2004-2006). An Update on Behalf of the Advisory Board of the 3rd and 4th Watching the Risk Symposium 13th and 15th European Stroke Conferences, Mannheim, Germany, 2004, and Brussels, Belgium, 2006. Cerebrovasc Dis 2007; 23: 75-80.

10. Hollander M., Hak A.E., Koudstaal P.J., et al. Comparison between measures of atherosclerosis and risk of stroke: the Rotterdam Study. Stroke 2003; 34: 2367-2372.

11. O’Leary D.H., Polak J.F., Kronmal R.A., et al.; Cardiovascular Health Study Collaborative Research Group. Carotid-artery intima and media thickness as a risk factor for myocardial infarction and stroke in older adults. $N$ Engl J Med 1999; 340: 14-22.

12. Lorenz M.W., von Kegler S., Steinmetz H., et al. Carotid intimamedia thickening indicates a higher vascular risk across a wide age range prospective data from the Carotid Atherosclerosis Progression Study (CAPS). Stroke 2006; 37: 87-92.

13. Cobble M., Bale B. Carotid intima-media thickness: knowledge and application to everyday practice. Postgrad Med 2010; 122: $10-18$.
14. von Sarnowski B., Lüdemann J., Völzke H., et al. Common carotid intima-media thickness and Framingham risk score predict incident carotid atherosclerotic plaque formation: longitudinal results from the study of health in Pomerania. Stroke 2010; 41: 2375-2377.

15. Polak J.F., Person S.D., Wei G.S., et al. Segment-specific associations of carotid intima-media thickness with cardiovascular risk factors: the Coronary Artery Risk Development in Young Adults (CARDIA) study. Stroke 2010; 41: 9-15.

16. Folsom A.R., Eckfeldt J.H., Weitzman S., et al.; American Heart Association. Relation of carotid artery wall thickness to diabetes mellitus, fasting glucose and insulin, body size, and physical activity. Atherosclerosis Risk in Communities (ARIC) Study Investigators. Stroke 1994; 25: 66-73.

17. Kissela B., Khoury J., Kleindorfer D., et al. Epidemiology of ischemic stroke in patients with diabetes. The greater Cincinnati/Northern Kentucky Stroke Study. Diabetes Care 2005; 28: 355-359.

18. Vigili de Kreutzenberg S., Coracina A., Volpi A., et al. Microangiopathy is independently associated with presence, severity and composition of carotid atherosclerosis in type 2 diabetes. Nutr Metab Cardiovasc Dis 2011; 21: 286-293.

19. van Hecke M.V., Dekker J.M., Nijpels G., et al. Are retinal microvascular abnormalities associated with large artery endothelial dysfunction and intima-media thickness? The Hoorn Study. Clin Sci (Lond) 2006; 110: 597-604.

20. Spence J.D. Technology insight: ultrasound measurement of carotid plaque - patient management, genetic research, and therapy evaluation. Nat Clin Pract Neurol 2006; 2: 611-619.

21. Bonora E., Kiechl S., Oberhollenzer F., et al. Impaired glucose tolerance, Type II diabetes mellitus and carotid atherosclerosis: prospective results from the Bruneck Study. Diabetologia 2000; 43: 156-164.

22. Brohall G., Odén A., Fagerberg B. Carotid artery intima-media thickness in patients with type 2 diabetes mellitus and impaired glucose tolerance: a systemic review. Diabet Med 2006; 23: 609-616.

23. Selvin E., Coresh J., Golden S.H., et al. Glycemic control, atherosclerosis, and risk factors for cardiovascular disease in individuals with diabetes: the atherosclerosis risk in communities study. Atherosclerosis Risk in Communities Study. Diabetes Care 2005; 28: 1965-1973.

24. Kaźmierski R. Biomechaniczne siły ścinania występujące w tętnicach szyjnych a rozwój miażdżycy. Post Hig Med Dośrw 2003; 57: 713-725.

25. Meyer M.F., Lieps D., Schatz H., et al. Influence of the duration of type 2 diabetes on early functional and morphological markers of atherosclerosis compared to the impact of coexisting classic cardiovascular risk factors. Exp Clin Endocrinol Diabetes 2008; 116: 298-304.

26. Hanefeld M., Koehler C., Henkel E., et al. Post-challenge hyperglycaemia relates more strongly than fasting hyperglycaemia with carotid intima-media thickness: the RIAD Study. Risk Factors in Impaired Glucose Tolerance for Atherosclerosis and Diabetes. Diabet Med 2000; 17: 835-840.

27. Chambless L.E., Heiss G., Folsom A.R., et al. Association of coronary heart disease incidence with carotid arterial wall thick- 
ness and major risk factors: the Atherosclerosis Risk in Communities (ARIC) Study. Am J Epidemiol 1997; 146: 483-494.

28. Kaźmierski R., Kozubski W., Watała C. Intima-media complex thickness of common carotid artery as a risk factor for stroke. Neurol Neurochir Pol 2000; 34: 243-253.

29. Silvestrini M., Cagnetti C., Pasqualetti P., et al. Carotid wall thickness and stroke risk in patients with asymptomatic internal carotid stenosis. Atherosclerosis 2010; 210: 452-457.

30. Tsivgoulis G., Vemmos K., Papamichael C., et al. Common carotid artery intima-media thickness and the risk of stroke recurrence. Stroke 2006; 37: 1913-1916.

31. Sander D., Schulze-Horn C., Bickel H., et al. Combined effects of hemoglobin A1c and C-reactive protein on the progression of subclinical carotid atherosclerosis: the INVADE study. Stroke 2006; 37: 351-357.

32. UK Prospective Diabetes Study (UKPDS) Group. Intensive blood-glucose control with sulphonylureas or insulin compared with conventional treatment and risk of complications in patients with type 2 diabetes (UKPDS 33). Lancet 1998; 352: 837-853.

33. UK Prospective Diabetes Study (UKPDS) Group. Effect of intensive blood-glucose control with metformin on complications in overweight patients with type 2 diabetes (UKPDS 34). Lancet 1998; 352: 854-865.

34. Turnbull F.M., Abraira R.J., Anderson R.J., et al. Intensive glucose control and macrovascular outcomes in type 2 diabetes. Diabetologia 2009; 52: 2288-2298.

35. Kawasumi M., Tanaka Y., Uchino H., et al. Strict glycemic control ameliorates the increase of carotid IMT in patients with type 2 diabetes. Endocrinol J 2006; 53: 45-50.

36. Shah A.S., Dolan L.M., Kimball T.R., et al. Influence of duration of diabetes, glycemic control, and traditional cardiovascular risk factors on early atherosclerotic vascular changes in adolescents and young adults with type 2 diabetes mellitus. J Clin Endocrinol Metab 2009; 94: 3740-3745.

37. Sigurdardottir V., Fagerberg B., Hulthe J. Preclinical atherosclerosis and inflammation in 61-year-old men with newly diagnosed diabetes and established diabetes. Diabetes Care 2004; 27 : 880-884.

38. EDIC Research Group. Effect of intensive diabetes treatment on carotid artery wall thickness in the epidemiology of diabetes interventions and complications. Epidemiology of Diabetes Interventions and Complications (EDIC) Research Group. Diabetes 1999; 48: 383-390.

39. Miyashita Y., Nishimura R., Nemoto M., et al. Prospective randomized study for optimal insulin therapy in type 2 diabetic patients with secondary failure. Cardiovasc Diabetol 2008; 29 : $7-16$.

40. Guo L.X., Pan Q., Wang X.X., et al. Effect of short term intensive multitherapy on carotid intima-media thickness in patients with newly diagnosed type 2 diabetes mellitus. Chin Med J 2008; 121: 687-690.

41. Lundby Christensen L., Almdal T., Boesgaard T., et al. Study rationale and design of the CIMT trial: the Copenhagen Insulin and Metformin Therapy trial. Diabetes Obes Metab 2009; 11: 315-322.

42. Zhou Q., Liao J.K. Pleiotropic effects of statins - basic research and clinical perspectives. Circ J 2010; 74: 818-826.
43. Arbel Y., Maharshak N., Gal-Oz A., et al. Lack of difference in the intimal medial thickness between the left and right carotid arteries in the young. Acta Neurol Scand 2007; 115: 409-412.

44. Luo X., Yang Y., Cao T., et al. Differences in left and right carotid intima-media thickness and the associated risk factors. Clin Radiol 2011; 66: 393-398.

45. Lee S.W., Hai J.J., Kong S.L., et al. Side differences of carotid intima-media thickness in predicting cardiovascular events among patients with coronary artery disease. Angiology 2011; 62: 231-236.

46. Polak J.F., Person S.D., Wei G.S., et al. Segment-specific associations of carotid intima-media thickness with cardiovascular risk factors: the Coronary Artery Risk Development in Young Adults (CARDIA) study. Stroke 2010; 41: 9-15.

47. Mackinnon A.D., Jerrard-Dunne P., Sitzer M., et al. Rates and determinants of site-specific progression of carotid artery intima-media thickness: the Carotid Atherosclerosis Progression Study. Stroke 2004; 35: 2150-2154. 